Thembela Kepe

Programme for Land and Agrarian Studies

University of the Western Cape,South Africa

Private Bag X17

Bellville, 7535 South Africa

Fax: 27219462864

Email: tkepe@sog.uwc.ac.za

Stream: Governance - Protected Areas

Discipline: Interdisciplinary

\title{
Communities, Entitlements and Nature Reserves: the Case of the Wild Coast, South Africa
}

\section{Introduction}

South Africa's post-apartheid government has committed itself to redressing the imbalances of the past, with the aim of improving the quality of life for millions of black people. Policy makers aim to develop policies that will have a positive effect on the poorest people of South Africa, particularly those who live in rural areas (ANC, 1994). In policy documents, communities are regarded as central to development and communitybased sustainable development is seen as the way to achieve these ambitious goals. In rural development programmes, new policies give communities responsibilities to decide on the directions to take. This is especially true of development in and around protected areas, where there is pressure on nature conservation authorities to relate to the welfare needs of the neighbouring communities (Environmental Affairs and Tourism, 1996). However, while these policies have good intentions, the assumptions on which they are based - such as those that suggest community coherence and harmonious interaction between rural communities and the environment - have become subject to increasing critique.

'Community-based sustainable development' has become central to the development rhetoric of the 'new' South Africa. As part of the new democratic dispensation, rural communities, it is argued, should now have a stake in their own development and a constitutional right to have a say in matters that affect their future. But what does this mean in practice, especially where development options are hotly contested? How can rights over land and resources be renegotiated when competing claimants argue that their rights should prevail? How can local voices be heard when large, regional economic development initiatives (such as the Spatial Development Initiative for the Wild Coast) are being planned? In areas near parks and reserves, how can new bargains be struck between local people and conservation authorities, given a long history of antagonism between them? These are just some of the questions being faced by policy-makers and development 
agents across rural South Africa, questions which are particularly pertinent in the case of protected areas along the Wild Coast in the former Transkei.

Through a case study of the Mkambati area of the Wild Coast, in the Eastern Cape Province of South Africa, this paper explores how the interaction of social and ecological dynamics affects the livelihoods of the rural poor who live near protected conservation areas. Using the environmental entitlements framework (see Leach, Mearns and Scoones, 1997), it seeks to explain how local people's use and management of resources within and outside the protected areas, are shaped by institutional arrangements at both local and macro-levels. Two livelihood cases are used to illustrate how resource-related community and institutional conflicts impact on livelihoods. The paper concludes by exploring some of the policy implications for rural people's livelihoods and protected area management interactions.

\section{The Wild Coast: people and protected areas}

Figure 1: Map of study area and location within Eastern Cape Province, South Africa

The case study area is situated on the eastern coast of South Africa, in the district of Lusikisiki (see Figure 1). This section of the Wild Coast falls within the boundaries of the former Transkei. The Transkei was one of South Africa's ten black homelands, and the first of four to gain self-rule in 1976. Since 1994, the Transkei has become part of the Eastern Cape Province. This province, one of nine in South Africa has a population of seven million people. The case study focused on the Mkambati area, which includes three communal settlements (namely Ngwenyeni, Baleni and Ndengane), Mkambati Nature Reserve and the TRACOR (Transkei Agricultural Corporation) state farm. The inhabitants of the area are Xhosa-speaking people and known as AmaMpondo, a group that mounted significant resistance to colonial rule from the nineteenth century (Mbeki 1965; Beinart 1982). While off-farm sources of income are important to local survival, local resources, including crop and livestock production and harvesting of a range of natural resources, make a vital contribution to people's livelihoods (Kepe 1997).

The mean annual rainfall is $1200 \mathrm{~mm}$, with at least $50 \mathrm{~mm}$ expected every month of the year. The area is dominated by poor soils of sandstone origin, although clay soil patches increase as one moves away from the coast. The combination of sandstone and high rainfall results in acidic, shallow sandy soils that are highly permeable (Tinley 1978). More than 80 per cent of the vegetation is sour grassland, with small patches of subtropical evergreen forests that are concentrated along river gorges and coastal sand dunes ${ }^{1}$. Amongst this vegetation are rare plants that have high conservation value, such as the endemic Pondo palm (Jubaeopsis caffra), locally known as uMkomba.

\footnotetext{
1. Archeological evidence suggests that this vegetation pattern of extensive grassland and small areas of woodland has probably been stable for a long time (Feely, 1987; Ellery and Mentis, 1992). This contrasts with some commentaries on environmental change in this area which sees the gorge forests as 'relics' of a
} 
Mkambati Nature Reserve has its beginnings in 1920 when more than 17,000 hectares of land was fenced off for a leper colony. Local livestock keepers who inhabited the grasslands close to the coast were forcibly removed to make way for buildings and livestock. Following improvement in the treatment of leprosy in the 1950s, the demarcated area ceased to serve its original purpose, and became a nature reserve $(6,000$ hectares) and a state agriculture farm (11,000 hectares) in 1977. Hundreds of herbivores were first introduced into the area in 1979. The reserve first operated as a hunting concern under a partnership between two successive private companies and the government, attracting tourists from all over the country. Due to alleged mismanagement, no more hunting was allowed after 1982, but the reserve currently supports 1700 wild herbivores. The reserve also supports local communities through opportunities for collection of various natural resources including thatch grass, medicinal plants, timber products and marine resources, as well as illegal hunting.

The following sections explore how different people living in the villages around Mkambati reserve make use of a variety of natural resources, both from within the reserve, from the state land and from within the village areas. Two livelihood strategies are highlighted - hunting and thatch grass collection. Both are significant for rural livelihoods in different ways and for different social actors. As the case studies show, access to and control over these resources is mediated by a set of interacting and overlapping institutions. For those resources derived from within the reserve boundary, institutional conflicts between villagers and the reserve management may arise. An analysis of these institutional interactions, overlaps and conflicts highlights the major trade-offs which need to be negotiated in any co-management arrangement between local villagers and reserve management.

\section{Seeking out livelihoods: endowments and entitlements}

\section{Game hunting}

Rural people who live on the coast of Pondoland have been hunting wild animals over many centuries (Feely 1987; Hunter 1979; Beinart 1982). Indeed, the early inhabitants of the area, who were hunters and gatherers, travelled in groups during their hunts (Perestrello 1554). However, according to Beinart (1982), the importance of hunting large game started to diminish during the nineteenth century. This coincided with the introduction of firearms, although hunting of small game, such as buck and birds, has continued (Hunter 1979). Many changes have taken place which have altered the role of hunting in rural people's livelihoods. Areas that were previously hunting grounds have been replaced by human settlements, fields and other infrastructure such as public roads. In addition much of the remaining game, that was previously readily available to rural

past extensive forest area. In fact, it appears that tree cover has increased in the recent period through planting of homestead woodlots and the encouragement of regrowth in and around settlement sites. 
hunters, has now been enclosed and protected in state parks, private game reserves and farms. Hunting in South Africa is now largely carried out by two groups - the urban rich, who normally do it for sport, as well as commercial purposes, and the rural poor, for whom hunting is another of their diverse range of livelihood sources. Legal access to hunting is now regulated by national legislation, as well as the amount of cash that individuals have. In many ways this excludes the rural poor.

A case study of how rural hunters living around Mkambati Nature Reserve gain access to wild game will be presented here, paying particular attention to the dynamic environment in which this takes place and the range of institutions that mediate access to wildlife (see Figure 2). The grasslands of Mkambati Nature Reserve are stocked with herbivores dominated by blesbok and wildebeest as well as other smaller animals such as baboons, rabbits and so forth. These grasslands serve as a hunting environment for the neighbouring rural communities.

Figure 2: Environmental entitlements analysis: the case of hunting in Mkambati reserve

Hunting is a male activity, although very young boys and unfit men do not go on major hunts, due to the many dangers associated with this activity. The youngest hunters are about 14 years of age, while the oldest are about 50. The majority of local hunters are unemployed and have limited alternative sources of livelihood compared to other villagers. While many of these hunters still hunt wild animals in order to supplement their maizebased diet, in recent years there has been a growing number who are motivated by the growing demand for certain animal species in the traditional medicine business. In such cases these hunters trade in parts of the animal to supplement their income.

There is another group of larger-scale commercial hunters, who also hunt in Mkambati (Skonhoft and Solstad 1996:168). Local perception is that these hunters are poachers. They hunt primarily for trophies, which is a more lucrative option than the sporadic hunting by local villagers. Two other lines of social difference distinguish the two types of hunters. Firstly, larger-scale commercial hunters usually reside far from the hunting location. In other words they are not considered as local people in terms of geographical location, and, indeed, in many other ways. Secondly, they are wealthier than most villagers, this being displayed by the modern and sophisticated equipment they use for hunting, from vehicles to guns and spot lights. The way these non-local hunters conduct themselves has encouraged local people to despise them greatly. Local perception is that larger-scale hunters are there to diminish local resources. This is reflected in comments by local people. For example, one man commented: "when we sit and discuss our village affairs and take particular decisions about how we do this and that, these hunters are not here. How can we then view them as part of us?" Another man commented that: "we can carry on accusing each other for something that we think was done by one of us, only to find out that it is these people who come here to just destroy our things without even asking us for permission". In terms of numbers, local hunters appear to be more numerous, but the impact of the larger scale hunters on wildlife populations is more noticeable. 
A complex array of institutions mediate access to game in Mkambati. Some of these have changed in nature over time, and some have even been supplanted by others. For example, in the past, when wild animals were still plentiful, the right of access to hunting grounds used to be open to all men of the chiefdom (Hunter 1979). After the dispossession of certain areas and their fencing off as nature reserves, rural hunters had their right of access effectively removed.

However, in Mkambati Nature Reserve, neighbouring villagers have, over the last 20 years, justified hunting by reference to the notion of $u$ kujola ${ }^{2}$. In terms of this notion, hunting in Mkambati Nature Reserve does not constitute a crime, because there is a general understanding among the villagers that the reserve is still part of their environment, an area they always had access to. This notion is not new in Pondoland. The early literature on the life of the Pondos before and after annexation refer to this concept: For example, Callaway (undated: 69) quotes Bishop Key who wrote of the Pondos a few years prior to the 1894 annexation:

\begin{abstract}
At one time theft was almost unknown in Pondoland. A Native has been known to follow a trader's wagon for miles for the purpose of restoring a handkerchief which had been dropped. But the resistance offered to the extradition of thieves has had a very bad effect on the people.......Protection has been shown to thieves from other tribes who have run into Pondoland with their spoil. This has been done simply, they will tell you, by way of retaliation. They consider that they have been badly treated, and, being the weaker party, they have used these means of repaying themselves by a system of passive resistance...
\end{abstract}

It is this passive resistance (cf. Scott, 1985, 1990), which has sustained this institution over the years, because ukujola is very non-confrontational. Hunters are vaguely aware of government regulations (e.g. the Environmental Conservation Decree of 1992) which forbid hunting in nature reserves without official permit. Since the idea of ukujola conflicts with these regulations, the hunters ensure that government officials do not see them inside the reserve, as it is understood that confrontation may result in arrest and even injury.

However, there is one issue on which all villagers and the reserve management agree; that is that commercial poachers from outside the local communities have absolutely no claim to legitimate access to wild game in Mkambati. Their access amounts to skilful theft of resources they have no historical claim to. The use of local resources by outsiders,

2. This is a local term that refers to locally legitimised "stealing" of a resource, based on historical claims to it, that predate the existing legislation. This is taken from another social norm, which has the same name, but refers to a love relationship between two young people of the opposite sex. According to local norms, the two young lovers must keep their affair secret from their respective parents or other relatives of a respectable status. Ukujola, in this case therefore means the two main participants had reached an understanding about their affair, but, because they are aware of possible consequences if parents found out, they do all in their power to hide from them. They would, however, firmly believe that they are not doing anything wrong. Ukujola is used the same way when referring to natural resources. 
without proper consultation with local inhabitants, is viewed as a sign of disrespect of local rules and regulations; poachers are therefore unpopular among local communities.

Throughout most of the twentieth century, government law in the rural areas of the former bantustans was enforced through chiefs and headmen. Given authority by the state over 'customary' affairs, so-called 'traditional' leaders were seen to be the appropriate representatives of local communities. This version of indirect rule was often resented by local people, and the legitimacy of the chiefs and headmen questioned. This came to a head with the rise of the civic organisations, mostly operating under the banner of the South African National Civic Organisations (SANCO). In recent years new forms of legitimate authority have been created, allowing new social actors to enter the local political arena. With the wider changes in national politics over the last decade, the question of who has legitimacy and authority in the rural areas has become increasingly difficult to answer (Manona 1997; Tapscott 1996). Today's rural communities are far from the idealised image of a harmonious, cohesive grouping with firm and effective traditional leadership rooted in the past. Since many 'communities' and their 'traditional leaders' were creations of colonial intervention, it is of course unlikely that such a pattern ever existed at all. However, such images remain powerful allures in the debate about comanagement and community-based sustainable development in South Africa. But it needs to be recognised that the reconfiguration of local political power and the increased contestation of leadership and authority makes such idealised notions of 'community' highly misleading.

New power relations at the local level, of course, have a major impact on the institutional matrix which affects people's resource access, as well as the ways different practices are interpreted and legitimised. For example, the rise of the civic organisations has affected the hunting activities of local communities in Mkambati Nature Reserve in a variety of ways. In their attempt to claim authority over the chiefs and headmen of the area and to be shown as the legitimate leaders who strive for development and justice, the civic organisations have encouraged the articulation of the institution and ukujola to gain rights of access to wild game and lay a claim to an environment that they believe belongs to the community. At the same time, civic organisation leaders have been attempting to initiate official negotiations with the reserve authorities, demonstrating their capacity to interact with government bureaucracy on behalf of the people. However, such behaviour does not impress everyone, and those with kin or other affiliations to headmen and chiefs dismiss such populist moves and back alternative strategies put forward by the so-called traditional leadership. The result, not surprisingly, is confusion. For villagers, negotiations around any local issue takes on a strong political slant, with allegiances, alliances and conflicts noted intently. For outsiders, including the conservation authorities eager to negotiate a co-management arrangement, the problem becomes who to initiate discussions with. As one official put it: "there is no community and no leadership; it's just one big minefield!"

Gaining access to the reserve is simply the first step in attempting to gain effective legitimate command over the game resources inside Mkambati Nature Reserve. There are 
other institutions involved in converting the right of access to Mkambati game into a set of entitlements. The first is the hunting party or ingqina. When people use the expression "ukuphum'ingqina" this implies a group hunting party. These hunting parties are drawn from homesteads, neighbourhood groupings (isithebe) or different villages (Hunter 1979). But the method used to catch game determines the composition of the hunting party. This can be explained through the words of a Baleni hunter:

There are people in Xholobeni village who use traps to catch animals. Consequently, we from Baleni have to inform them whenever we intend going for a hunt to ensure that they disarm the traps, which could seriously harm our dogs. In other words, we either have to invite them to join our ingqina or give us a right of way on their side of the forest and Mkambati, by being considerate of our dogs. ${ }^{3}$

This mutual working relationship among different hunters is not only important for the sake of the dogs. The manner in which the herbivores are hunted in Mkambati also requires co-operation among a wide range of social actors. Hunters burn grass strips close to the reserve boundary to encourage new growth. This, in turn, attracts game, which can easily be shot at. This strategy requires inter-group cooperation in coordinated burning to avoid having many newly burnt sites that could end up confusing the game. Conservation officials, on the other hand, counter-burn in the centre of the reserve to attract the game away from the boundary zone, leading one reserve official to refer to a "tug of war with fire".

Hunters use trained dogs and guns when hunting. Guns are particularly important, because the activity has to take place very quickly to avoid being discovered by the reserve guards. While many hunters make their own guns, others are bought in both local and external markets or are borrowed. Borrowing is mostly mediated by kinship networks and by an ethic of mutual aid (ukuncedisana). It is considered safer to put your trust in your immediate kinspeople and people of the neighbourhood rather than other people who are more distantly related. Those who lend guns (or even hunting dogs), do get some reward for doing so, and it is a common practice in the social life of the Pondo people to share a portion of produce as a token of appreciation with those from whom assistance was received.

Depending on the type of animal that is hunted, different sets of entitlements are derived. If a wildebeest is hunted, for instance, the tail is the most important immediate entitlement which later can be converted into yet another entitlement - cash, through its sale to the traditional medicine market in Durban. Wildebeest tails have been known to fetch very high prices in the market. The venison, hides, horns and so forth can also be converted to cash income when the market allows.

Access to game within the reserve is likely to continue until the government can no longer ignore people's claims to resources, including land, that are now under government protection. It is clear that trying to prevent "illegal" hunting through policing only is not a

3 Interview with a 16 year old hunter from Baleni. 
viable solution, because ukujola is non-confrontational and it is unlikely that there will be an open clash with law enforcement agents under the present circumstances. However, unregulated poaching by outsiders has the potential to disrupt local game management strategies severely. A potential therefore exists for co-management arrangements between local hunters who currently gain access to wild game through ukujola and the conservation department, with both joining forces to exclude commercial poachers from the area.

\section{Thatch grass collection}

Another important resource available within the reserve is thatch grass. Certain grass species such as Cymbopogon validus (umqungu), Miscanthus capensis (umthala) and Hyperrenia spp (iDobo) have a very high value as thatching material. Of these three grasses, Cymbopogon validus is the most preferred, due to its smooth finish (Johnson 1982). Spatial and temporal variations in ecological sites in the case study area result in regular shortages of Cymbopogon validus. The high sand content of the soils in the area is unfavourable for C. validus (Shackleton 1994), suggesting that this type of grass has probably never been very abundant. Cymbopogon validus is currently found in three local environments - Mkambati Nature Reserve, TRACOR state farm land and the village areas. In the village it is either protected from grazing and fire or planted by some individuals. In general, the grass is very patchily distributed, growing largely on heavier soils or in areas with previous disturbance (e.g. settlement sites, termite mounds, old fields etc.). $C$. validus is presently most abundant in Mkambati Nature Reserve, where in the late 1980s it covered more than 500 hectares (Shackleton 1990). This is the major site for collection by neighbouring villagers. The grass is spread out in numerous patches that range in size from one to 87 hectares. Certain sites considered by reserve management as ecologically sensitive (e.g. sites that are very close to indigenous swamp forests) are excluded from harvesting.

In the past there were areas in the villages reserved for C. validus and Hyperrenia spp which were protected from grazing and fire. Offenders were fined by the chief or warned. With the gradual decline in the legitimacy of the institution of chieftaincy, combined with population increase, the protection that was once afforded this common pool resource is now effectively gone. Uncontrolled burning has resulted in increasing scarcity of $C$. validus in all areas. Grass shortages have led to investment in C. validus management in the village. This has involved, firstly, the protection of patches around the homestead from fire and, secondly, some villagers plant the seeds of $C$. validus in their fields. Thus, within the village areas, heightened resource scarcity has resulted in institutional innovation, with former arrangements of village-wide communal regulation of burning and grazing giving way to more localised neighbourhood-level regulation of resource use and even privatisation of grass patches through protection or planting.

While detailed studies were done during the 1980s on the use of $C$. validus by local people and the ecological impact of its harvesting (Shackleton 1990), institutional aspects of this activity have been largely ignored. Thatch grass remains important for many people's 
livelihoods as it is essential for most roofing in the area, but with increasing scarcity of the favoured species, more effective resource management mechanisms are required. With the major source of thatch grass being the reserve area, co-management of this resource is clearly one option. The following section explores how different people gain legitimate and effective command over the thatch grass resource within different environments, focussing on the institutional factors which mediate resource access and the implications this has for co-management options.

Figure 3: Environmental entitlements analysis: thatch grass collection

In Mkambati grass collectors are able-bodied women from the neighbouring villages. This includes those who collect grass for personal use, those who collect for sale and those who collect for others, as hired labourers. Women who collect to sell or who are hired labourers mostly come from de facto female headed households, and largely depend on collection of other plant material for sale. Within the village, grass collectors include those who make use of either planted grass areas (including some men) or grass patches that are protected from fire through early burning practices.

Management regulations of Mkambati Nature Reserve influence rights of access to thatch grass. During the leper reserve era, villagers gained access to grass through kin who worked in Mkambati. Currently, payment of cash to reserve management for unlimited headloads (izithungu) of grass is formally required ${ }^{4}$. "Bribery" of guards through offering sexual favours is common among unmarried women, allowing them preferential access to certain grass patches in the reserve. The comment of one married woman sheds some light on this:

If you are married you really struggle when the grass is limited. That man will take the amadikazi [unmarried or divorced or widowed women] and put them where the grass is nice and thick, because he can get sexual favours from them. Since we are married and can't offer him what those amadikazi can offer, he treats us like we do not exist. ${ }^{5}$

While no longer as common as it was, the notion of ukujola is also important for legitimating informal rights over grass in Mkambati, and avoiding payments. In the villages, the protection of grass from burning or planting it in field plots secures rights of access for those who either invest in the protection process or who own the land. Other villagers who require grass in the villages, but are not involved in its protection or planting, have to trade with those who do.

In all the environments where grass is collected, various local institutions are important for mobilising labour for its collection or transportation to the site where it will be used.

\footnotetext{
4 Villagers pay ten rands per person, of which five rands is supposed to remain with the reserve, while the other five rands goes to a community fund. However, this sharing arrangement has never worked out. The reserve now keeps all the money.

5 A married woman's comment during a thatch grass collectors' focus group.
} 
Women take the sole responsibility for cutting thatch grass in Mkambati and TRACOR, while men may be occasionally involved in planting and protection of the grass in the villages. Other social actors within a household, who are not able to collect thatch grass from Mkambati themselves, gain entitlements through kinship linkages. Elderly women, for instance, can send their daughters to do the cutting for them. Trading and hiring arrangements are among the range of institutions that mediate access to thatch grass for those who cannot collect.

Due to the long distance between some villages and Mkambati, transportation becomes crucial for gaining grass. Trucks are therefore hired, costing about one hundred rands per load. However, villagers who are much closer Mkambati (e.g. from Ndengane), make use of other local institutions. Amalima (work parties) are organised by the host household, where the participants first carry the grass on their heads or shoulders before enjoying the beer or food that is provided. The provision of beer or food requires that the hosts should have some resources to be able to provide these. Those who are not in a position to provide the beer or food, but still need help to transport the grass, call on another institution - mutual aid or ukuncedisana.

A variety of institutions are therefore important in gaining access to thatch grass (see Figure 3). During the endowment mapping process these include the reserve's regulations, combined with informal mechanisms of gaining access through bribery of ukujola. The entitlement mapping process, in turn, relies on a variety of institutions for mobilising labour and transport, ranging from informal kin networks and sharing relationships to formal contracting and hire. What are the implications for co-management options of this analysis? Unlike in the case of hunting, it appears that there is no fundamental institutional conflict between grass collectors and the reserve management. The two group's objectives are appparently compatible and conflicts are rare, making joint use of thatch grass resources in the reserve a possibility.

\section{Transforming the environment}

In order to assess the viability of different co-management options, trade-offs in environmental impact have to be considered. Both hunting and thatch grass collection inevitably transform the environment to some degree. The grasslands of the Mkambati area are the product of long histories of burning, grazing by wild and domestic animals and the collection of plant products. They are not pristine landscapes, but are created by human action. The choice of what type of environment to have is therefore an active one. And the ideal landscape of course depends on who you are. This makes negotiations around environmental issues particularly sensitive.

So, what should the Mkambati reserve environment look like? The village hunters may wish for extensive game, with grazing managed by heavy burning to create a short, nutritious grass sward. But those women who collect thatch grass in the reserve would strongly object to this vision, as the heavy burning regularly destroys the thatch grass and this, combined with intensive grazing, eventually eliminates the favoured grass species, $C$. 
validus. Others may have other ideas. The current reserve management, for instance, has a management plan that sees plant biodiversity protection through managed, rotational grazing and burning and complete burning and grazing protection in more vulnerable spots as the prime motive. Yet, in the past, reserve managers aimed at maximising hunting revenues through the artificial stocking of certain game and trophy species. With the planned construction of coastal road, many business people have the capturing of tourist potential as a key priority, emphasising the scenic beauty of the rolling grasslands, the wildlife and the seashore.

Some resource use options are clearly more compatible than others, with greater prospects for resolving conflicts and dealing with overlapping rights. For example, thatch grass collection appears to be perfectly in tune with many nature conservation objectives, while hunting is evidently not. The trade-offs between different options therefore need to be made explicit in any discussion about co-management.

\section{Prospects for co-management?}

This paper has illustrated the complexities of people, livelihood and environment relations in a situation of social and economic change. In particular, the use of the environmental entitlements framework to analyse such interactions proved useful.

The emphasis on institutions has highlighted the serious conflicts around authority at a local level, with major effects on people's livelihood (e.g. chieftaincy and civic associations); that conflicts also exist between the national legal framework and local understanding of what is legitimate (e.g. government legislation on nature reserves and ukujola); and that there is a high degree of complementarity between institutions mediating access to natural resources. For example, sexual divisions of labour, kinship network, neighbourhood groupings (isithebe), mutual aid norms (ukuncedisana), work parties (amalima) and so on, complement each other in mobilising labour resources.

The case study has also shown that understanding social difference is key to exploring options for the use of environmental resources. At a local level, there are ongoing conflicts among actors delineated according to different lines of social difference. For example, it is able-bodied, poor women who collect thatch grass in the nature reserve, while it is able-bodied poor men or wealthier men (poachers) who do the hunting (indicating differences along lines of health, gender and wealth). It is useful to have a clear understanding of these social differences and any conflict that might exist between them in terms of who uses what resource. This, in turn, can inform participatory and comanagement arrangements between local communities and protected areas authorities.

Clearly the prospects for co-management between different rights holders requires an understanding of how different social actors view the environment and its use. This, in turn, requires identifying the areas of conflict and complementarity. The complex task of unravelling the tangle of institutional relationships which mediate different people's access 
to different resources is, however, an essential precursor to any negotiation between competing groups. The environmental entitlements approach provides a framework for doing just that. With the issues explicit and the overlaps, complementarities and conflicts laid bare, the difficult task of seeking acceptable outcomes through negotiation, debate, and ultimately, compromise can start.

Such processes are a central part of successful development at the local level. In my view, a more realistic approach to the many real and difficult challenges of co-management may result in greater chances of really sustainble community-led development initiatives on the ground. As with so many rural development initiatives around the world, attempts to seek co-management arrangements in and around nature reserves along South Africa's Wild Coast are affected by conflict, more than consensus. Often, development practitioners and policy-makers recognise these conflicts in general terms, turning a blind eye to the details. The environmental entitlements framework could be helpful in ensuring such conflict issues, and the institutional dimensions of them, are brought more to the fore.

\section{References}

African National Congress, 1994, Reconstruction and Development Programme, Johannesburg: African National Congress

Beinart, W., 1982., The Political Economy of Pondoland 1860 to 1930, Johannesburg: Ravan Press

Callaway, G., Undated, Pioneers in Pondoland, Lovedale: Lovedale Press

Ellery, W. and Mentis, M., 1992, 'How old are South Africa's grasslands?' in P. Furley, J. Proctor, and J.A. Ratter, (eds), Nature and Dynamics of Forest-Savanna Bounaries, London: Chapman and Hall, 283-292

Environmental Affairs and Tourism, Department, 1996, Green Paper on the Conservation and Sustainable Use of South Africa's Biological Diversity. DEAT, Pretoria

Feely, J. M., 1987, 'The Early Farmers of Transkei, Southern Africa', Cambridge Monographs in African Archaeology, 24

Hunter, M., 1979, Reaction to Conquest: Effects of Contact with Europeans on the Pondo of South Africa, Abridged Edition. Cape Town: David Philip

Johnson, C.T., 1982, 'The living art of hut building in Transkei', Veld and Flora, December:109-110

Kepe, T., 1997, 'Report of fieldwork, Mkambati, Eastern Cape', PLAAS, University of the Western Cape, South Africa 
Leach, M., Mearns, R. and Scoones, I., 1997, 'Environmental Entitlements: A framework for understanding the institutional dynamics of environmental change', IDS Discussion Paper, No 359, Brighton: IDS

Manona, C., 1997., 'The chieftaincy debate', Sunday Times

Mbeki, G., 1964, South Africa: The Peasants' Revolt, Harmondsworth: Penguin Books

Perestrello, M. de M., 1554, 'Narrative of the wreck of the ship Sao Bento', in G.M.

Theal, (ed), 1898, Records of South - Eastern Africa, Vol 1, Cape Town: Government of the Cape Colony

Scott, J., 1985, Weapons of the Weak. Everyday Forms of Peasant Reisistance, New Haven: Yale University Press, CT

Scott, J., 1990, Domination and the Arts of Resistance: Hidden Transcripts, Yale New Haven: Yale University Press, CT

Shackleton, S.E. and Shackleton, C.M, 1990, 'Socio - economic importance of Cymbopogon validus in Mkambati Game Reserve, Transkei', South African Journal of Botany, Vol 56, (6): 675-682

Shackleton, S.E., 1994, 'Habitat factors influencing the distribution of Cymbopogon validus in Mkambati Game Reserve, Transkei', African Range and Forage Science, 11 (1): $1-6$

Skonhoft, A. and Solstad. J.T., 1996, 'Wildlife management, illegal hunting and conflicts. A bioeconomic analysis'. Environment and Development Economics, Vol 1: 165 - 181

Tapscott, C., 1996, 'The institutionalisation of rural Local Government in Post-Apartheid South Africa', Konrad-Adenauer-Stiftung, Occasional Papers: 13-21

Tinley, K.L., 1978, Mkambati Nature Reserve: An Ecological and Planning Study, Pretoria: Farrell and van Riet Landscape architects and Ecological Planners 